\title{
コンクリート充填鋼管長柱の耐力評価式 DESIGN FORMULA OF SLENDER CONCRETE FILLED STEEL TUBULAR COLUMNS
}

\author{
津田惠吾*1，松井千秋*2，石橋靖夫*3 \\ Keigo TSUDA, Chiaki MATSUI and Yasuo ISHIBASHI
}

\begin{abstract}
The objective of this paper is to propose a refined strength formula of slender concrete filled steel tubular columns. On the basis of experimental results, current AIJ design formula is examined, and it is found that the supposed strength of a concrete column is so conservative when the buckling length-section depth ratio becomes large. Accordingly, an elasto-plastic analysis is performed to obtain the concrete column strength. After the concrete column strength is proposed, to use the concrete strength instead of the supposed strength is proposed in the current AIJ design formula. It is shown that experimental maximum load is well estimated by the proposed method.
\end{abstract}

Keywords:composite column, concrete column, maximum strength, buckling

合成柱，コンクリート柱，終局耐力，座屈

\section{1. 序}

コンクリート充填鋼管柱は，断面を構成する材料の強度を有効に 発揮させることができるため, 今後, 高張力鋼や高強度コンクリー トの利用が促進されると，他の構造に比べて断面が小さくなり，細 長い柱が設計される。また, 設計の自由度から, 強剛な耐横力構と 組み合わせて細長い柱が用いられる可能性がある．その結果，柱の 安定性に対する検討が重要になって来る ${ }^{1)}$.

しかしながら，わが国では，建築構造を構成するラーメンの柱材 は太短いものが多く，これまでの研究は主として短柱に関するもの が多かった，近年，上記のようにコンクリート充填鋼管柱の特長を 生かした長柱が実際に設計されて来ている.SRC長柱に対しては柴 田が耐力評価式を提示しているが2, ,3), コンクリート充填鋼管長柱の 研究は我国ではあまりなされていない。

コンクリート充填鋼管長柱の設計式としては，許容応力設計法に 対する許容耐力が鉄骨鉄筋コンクリート構造計算規集・同解説 4) (以 下 SRC 規毦と略す）に，終局酎力が鋼管構造設計施工指針・同解説 ${ }^{5)}$ （以下鋼管指針と略す）に示されている.この設計式の考え方は若林 ら6)によるものであるが，実験的検証は不十分であり，どの程度の 安全率があるかが不明であり, 検討が必要である7).

以上の点を鑑みて, 筆者ら ${ }^{8)}$ は, 断面形, 座屈長さと断面せいの
比, 圧縮力の偏心距離を実験変数に選び, 中心および偏心圧縮力を 載荷する基礎的，系統的な実験を行うことにより，鋼管指針に示さ れているコンクリート充填鋼管長柱に対する設計式の検討を行った. また，圧縮力を受けるコンクリート充填鋼管長柱の耐力は鋼管柱の 座屈荷重とコンクリート柱の座屈荷重を累加することにより精度良 く評価出来ることを解析的に示し9, さらに現行の圧縮耐力評価法 を，筆者らの実験も含めてわが国で行われた座屈実験結果に基づい て検討した ${ }^{10)}$.

本論文では，コンクリート充填鋼管長柱のより合理的な設計式を 提示することを目的とする.

2 章で耐力評価式の検討に用いた実験の概要を，3章で現行の設計 式の概要と, 現行設計式がコンクリート柱の耐力を過小評価してい ることを示す.4章では解析結果に基づきコンクリート柱の耐力式を 提示する. 5 章でコンクリート柱の耐力として4章で示した耐力を用 い，その他は現行の設計式にしたがってコンクリート充填鋼管柱の 耐力を算定すれば，実験耐力を精度良く評価できることを示す。

\section{2. 実験の概要}

本章では, 耐力評価式の検討に用いた実験の概略について記す.
*1 九州大学工学部建築学科 助手. 工博

*2 九州大学工学部建築学科 教授. 工博

*3 九州大学工学部建築学科 大学院生 $\cdot$ 工修
Research Assistant, Dept. of Architecture, Kyushu Univ., Dr. Eng.

Professor, Dept. of Architecture, Kyushu Univ., Dr. Eng.

Graduate Student, Dept. of Architecture, Kyushu Univ., M. Eng. 


\section{1 実験計画}

SRC 規準では，座屈長さ（Lk）が断面せい（D）の12倍以下のも のは短柱として取扱い，12倍を超えるものは圧縮力とたわみによる 2 次曲げの影響を考慮した長柱としての取扱いをすることが規定さ れている，座屈長さの上限は，柱の場合は最小径の30倍以下，圧縮 材では50倍以下と規定されている.

著者らは，短柱から長柱までの広範囲な部分をカバーする中心あ るいは偏心圧縮力を載荷する実験を下記の実験变数を選んでおこ なった ${ }^{8}$.

1) 断面形: 角形, 円形

2 ) 座屈長さ・断面せい比 (Lk/D) : 4, 8, 12, 18, 24, 30

3 ) 偏心距離 (e)/断面の核半径 $(\kappa): 0,1,3,5$

図- 1 に示すように材の両端に等偏心の荷重Nを載荷する実験を, 比較のための中空銅管柱の中心圧縮試験を 12 体含め, 計 60 体行っ た. 荷重の偏心距離 $\mathrm{e}$ は, 断面の核半径 $\kappa$ （角形断面で $\kappa=2.5 \mathrm{~cm}$, 円形断面で $\kappa=2.1 \mathrm{~cm}$ ）を基準に取った. なお, $\mathrm{Lk} / \mathrm{D}=30$ の 中空角形 鋼管の細長比 $\lambda$ は 76, 中空円形鋼管の $\lambda$ は 87 である.

\section{2 . 2 試釦体}

実験に用いた角形鋼管の公称断面は $150 \times 150 \times 4.5$ (STKR400)，円形 鋼管の公称断面は $165.2 \phi \times 4.5$ （STK400）である. 残留応力を除去 するための熱処理は行っていない. 表-1に鋼管の実測断面寸法を示 す.

材長を断面せいの3倍とした中空鋼管の短柱圧縮試験結果および コンクリートシリンダー $(10 \mathrm{~cm} \phi \times 20 \mathrm{~cm})$ の圧縮試験結果を表 -2 に示す. 鋼管の降伏応力度 $\sigma y$ は $0.2 \%$ オフセット耐力である.コン クリートの圧縮強度の平均值は角形で $325 \mathrm{~kg} / \mathrm{cm}^{2}$, 円形 $417 \mathrm{~kg} / \mathrm{cm}^{2}$ で あった．㓦力の算定には表 -1 および表 -2 に示す值を用いた。

\section{3. 鋼管指針の設計式による耐力}

本章では、鋼管構造設計施工指針·同解説に示されたコンクリート 充填鋼管長柱の設計式による耐力Nsrc の算定について示す。

\section{1 鋼管指針の耐力式による耐力 Nsrc}

鋼管指針に示されているコンクリート充填鋼管長柱の終局耐力は， 2 次曲げの影響を考慮して決められた鋼管長柱とコンクリート長柱 の耐力を，式 (1)，(2) に示すように，2次曲げの影響を修正して累 加した累加強度方式の設計式である.この式は図-2に示すように短

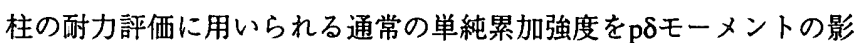

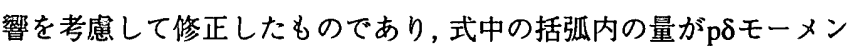
トに関係する量である。

$\mathrm{Nu} \leqq \mathrm{cNcu}$ または $\mathrm{Mu} \geqq \mathrm{sMu} 0(1-\mathrm{cNcu} / \mathrm{Nk})$ のとき

$$
\mathrm{Nu}=\mathrm{cNu}
$$

$$
\mathrm{Mu}=\mathrm{cMu}+\mathrm{sMu} 0(1-\mathrm{cNu} / \mathrm{Nk})
$$

$\mathrm{Nu}>\mathrm{cNcu}$ または $\mathrm{Mu}<\mathrm{sMu} 0(1-\mathrm{cNcu} / \mathrm{Nk})$ のとき

$$
\begin{aligned}
& \mathrm{Nu}=\mathrm{cNcu}+\mathrm{sNu} \\
& \mathrm{Mu}=\mathrm{sMu}(1-\mathrm{cNcu} / \mathrm{Nk})
\end{aligned}
$$

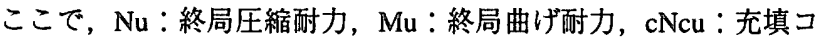
ンクリート長柱が圧縮力のみを受ける場合の終局圧縮耐力 (鋼管指 針ではコンクリートの断面せいの5パーセントの偏心がある時の耐

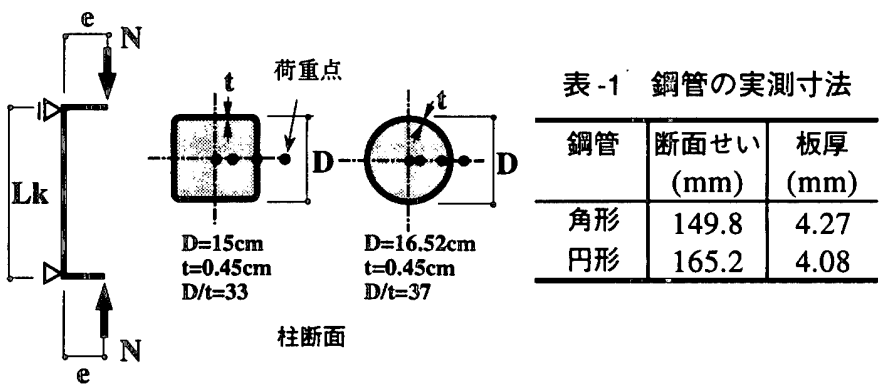

図-1 荷重条件

表-2 鋼管の短柱圧縮試倹結果と

$$
\text { コンクリートシリンダーの圧縮試験結果 }
$$

\begin{tabular}{c|c|c|c}
\hline 断面 & $\begin{array}{c}\text { 降伏応力度 } \\
\sigma \mathrm{y}\left(\mathrm{t} / \mathrm{cm}^{2}\right)\end{array}$ & $\begin{array}{c}\text { 圧縮強度 } \\
\sigma \mathrm{u}\left(\mathrm{t} / \mathrm{cm}^{2}\right)\end{array}$ & $\begin{array}{c}\text { コンクリート圧縮強度 } \\
\mathrm{Fc}\left(\mathrm{kg} / \mathrm{cm}^{2}\right)\end{array}$ \\
\hline 角 & 4.20 & 4.27 & 325 \\
\hline 円 & 3.60 & 4.06 & 417 \\
\hline
\end{tabular}

カとして算定), $\mathrm{cNu}$ ：充填コンクリート長柱の終局圧縮耐力, $\mathrm{cMu}$ ：

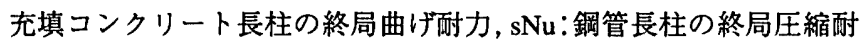
力, $\mathrm{sMu}$ : 鋼管長柱の終局曲げ耐力, $\mathrm{sMu} 0$ : 龬管部分が曲げモーメ ントのみを受ける場合の終局曲げ耐力, $\mathrm{Nk}$ ：柱のオイラー座屈耐力 であり，下式で算定する.

$\mathrm{Nk}=\pi^{2}(\mathrm{cE} \mathrm{cI} / 5+\mathrm{sE} \mathrm{sI}) / \mathrm{Lk}^{2}$

ここに, Lkは柱の座屈長さ, $\mathrm{cE}, \mathrm{sE}$ はそれぞれコンクリート, 鋼 管部分のヤング係数, cI， sI は断面 2 次モーメントである.

\section{2 鋼管柱の耐力}

鋼管柱の終局酎力に関する sMu-sNu相関曲線は, 鋼構造塑性設計 指針 "1)による柱材の耐力式で得られ，下式で表せる.

$\mathrm{sNu} / \mathrm{sNcr}+\mathrm{CM} \cdot \mathrm{sMu} /\left\{\left(1-\mathrm{sNu} / \mathrm{sN} \mathrm{N}_{\mathrm{E}}\right) \cdot \mathrm{su} 0\right\}=1$

ここで, sNcr：柱の座屈強度, $\mathrm{sN}_{\mathrm{E}}$ ：柱の曲げ面内におけるオイ ラー座屈強度, であり次式で与えられる。

鋼管柱の座屈強度 $\mathrm{sNcr}$ は, 鋼構造塑性設計指針 ${ }^{111}$ より， $\lambda 1=1 / \pi$. $(\sigma \mathrm{y} / \mathrm{sE})^{0.5} \cdot \lambda(\lambda$ は細長比) として,

$$
\begin{aligned}
& 0 \leqq \lambda 1 \leqq 0.3 \\
& \mathrm{sNcr}=\mathrm{sNy} \\
& 0.3 \leqq \lambda 1 \leqq 1.3 \\
& \mathrm{sNcr}=\{1-0.545(\lambda 1-0.3)\} \mathrm{sNy} \\
& 1.3 \leqq \lambda 1 \quad \mathrm{sNcr}=\mathrm{sNE}_{\mathrm{E}} / 1.3
\end{aligned}
$$

ここで, sNyは柱の降伏軸力である.

鋼管柱のオイラーの座屈強度 $\mathrm{SN}_{\mathrm{E}}$ は下式で与えられる.

$\mathrm{sN}=\pi^{2} \cdot \mathrm{sE} \cdot \mathrm{sI} / \mathrm{Lk}^{2}$

ここで, sE は鋼管のヤング係数, sI は鋼管の断面 2 次モーメント である。

$\mathrm{C}_{\mathrm{M}}$ は等価曲げモーメント係数, sMu0は鋼管の全塑性モーメントで ある。 

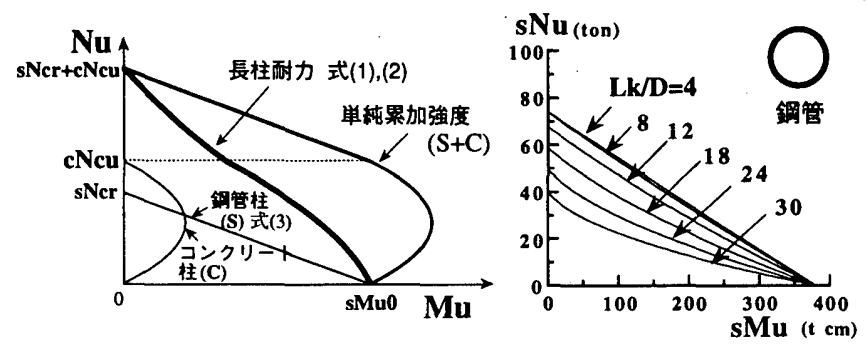

図-2 長柱の累加強度
图-3 鋼管柱の耐力

酎力式 (4)を sMuについて解けば, 下式が得られる.

$\mathrm{sMu}=(1-\mathrm{sNu} / \mathrm{sNcr}) \cdot(1-\mathrm{sNu} / \mathrm{sN} \mathrm{E}) \cdot \mathrm{sMu} 0 / \mathrm{CM}$

(7)

この形式の設計式は論理的には飛躍があることが指摘されている が 12)，設計式として世界各国で使われており，歴史的に検証を受け

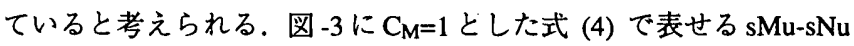
関係を 2 章実験概要で示した円形断面 $(165.2 \phi \times 4.5)$ について示す. 3. 3 コンクリート柱の耐カ

コンクリート柱の $\mathrm{cMu}-\mathrm{cNu}$ 相関曲線は $\mathrm{RC}$ 長柱に対する $\mathrm{ACI}$ 規準 にならった式を採用している，すなわち，全塑性に対する相関式の モーメントの項に軸力による拡大係数 $(=1 /(1-\mathrm{cNu} / \mathrm{cNk}))$ を乗じた ものとして下式となる.

\section{角形断面の場合}

$\mathrm{cMu} /\left(\mathrm{cb}^{2} \cdot \mathrm{cD}^{2} \cdot \mathrm{cru} \cdot \mathrm{Fc}\right)=$

$\mathrm{cNu} / 2 \cdot(\mathrm{cb} \cdot \mathrm{cD} \cdot \mathrm{cru} \cdot \mathrm{Fc}) \cdot(1-\mathrm{cNu} / \mathrm{cb} \cdot \mathrm{cD} \cdot \mathrm{cru} \cdot \mathrm{Fc}) \cdot(1-\mathrm{cNu} / \mathrm{cNk})$

ここで, cb：コンクリート断面の幅, $\mathrm{cD}$ : コンクリート断面のせ い, cru：コンクリートの圧穛強度の低隇係数, Fc：コンクリートの 設計基準強度である。

\section{円形断面の場合}

$\mathrm{cNu} /\left(\mathrm{cD}^{2} \cdot \mathrm{cru} \cdot \mathrm{Fc}\right)=(\theta-\sin \theta \cdot \cos \theta) / 4$

$\mathrm{cMu} /\left(\mathrm{cD}^{3} \cdot \mathrm{cru} \cdot \mathrm{Fc}\right)=\sin ^{3} \theta / 12 \cdot(1-\mathrm{cNu} / \mathrm{cNk})$

式 (8),(9)中の cNk は次式で表現される.

$\mathrm{cNk}=\pi^{2} \cdot \mathrm{cE} \cdot \mathrm{cI} /\left(5 \mathrm{Lk}^{2}\right)$

ここにcEはコンクリートのヤング係数, cIはコンクリート部分の 断面 2 次モーメントである.

ただし，式(8)，(9)で曲げモーメントが小さい場合でも，圧縮力に 対してコンクリートの断面せいの少なくとも $5 \%$ の偏心を考えるこ とになっている，したがって，式 (1) のcNcuはコンクリートの断面 せいの 5\%の偏心がある時の耐力として式 (8) あるいは (9) の左辺の $\mathrm{cMu}$ に $\mathrm{cNcu} \cdot \mathrm{cD} / 20$ を代入し，また $\mathrm{cNu}=\mathrm{cNcu}$ として算定する. 式 (8)より $\mathrm{cMu}=0$ としてモーメントが作用しない場合の圧縮耐力を求 めると, $\mathrm{cNu}=\mathrm{cb} \cdot \mathrm{cD} \cdot \mathrm{cru} \cdot \mathrm{Fc}$ あるいは $\mathrm{cNcu=cNk}$ となる。材長が長くなる と，圧縮耐力 $\mathrm{cNcu}$ は cNk に支配されることがわかる。

角形断面の場合 $\mathrm{cNcu}$ は次式となる.

$\mathrm{cNcu}=\left\{\mathrm{cNu} 0+\mathrm{cNk}-\left(\mathrm{cNu}^{2}-1.6 \mathrm{cNk} \cdot \mathrm{cNu} 0+\mathrm{cNk}^{2}\right)^{0.5}\right\} / 2$

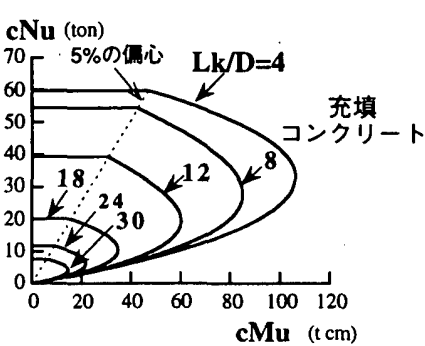

図-4 コンクリート柱の耐カ

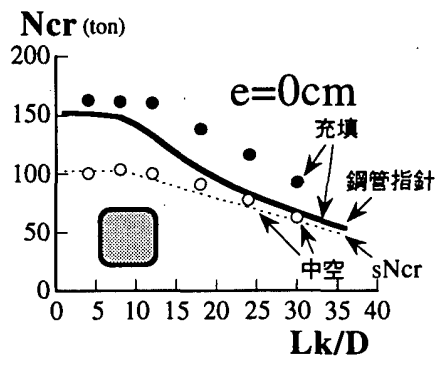

図-5 カラムカーブ

ここで, $\mathrm{cNu} 0=\mathrm{cb} \cdot \mathrm{cD} \cdot \mathrm{cru} \cdot \mathrm{Fc}$ である.

図 -4 に 2 章実験概要で示した円形断面コンクリート柱 $(156.2 \phi)$ の $\mathrm{cMu}-\mathrm{cNu}$ 関係を示す.

\section{3. $4 \mathrm{Mu}-\mathrm{Nu}$ 相関曲楾}

以下に式 (1)，(2) を変形して求めた角形断面の $\mathrm{Mu}-\mathrm{Nu}$ 相関曲線 式を示す（円形断面の場合は解析的表現は得られない）。

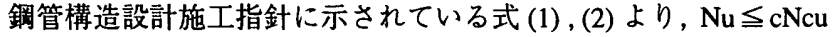
のとき， $\mathrm{Nu}=\mathrm{cNu}, \mathrm{Nu}>\mathrm{cNcu}$ のとき, $\mathrm{sNu}$ は $\mathrm{sNu}=\mathrm{Nu}-\mathrm{cNcu}$ となるか ら,

$\mathrm{Nu} \leqq \mathrm{cNcu}$ または $\mathrm{Mu} \geqq \mathrm{sMu} 0(1-\mathrm{cNcu} / \mathrm{Nk})$ のとき

$\mathrm{Mu}=$

$\mathrm{Nu} / 2 \cdot \mathrm{cD} \cdot(1-\mathrm{Nu} /(\mathrm{cb} \cdot \mathrm{cD} \cdot \mathrm{cru} \cdot \mathrm{Fc})) \cdot(1-\mathrm{Nu} / \mathrm{CNk})+\mathrm{SMu0} \cdot(1-\mathrm{Nu} / \mathrm{Nk})$

$\mathrm{Nu}>\mathrm{cNcu}$ または $\mathrm{Mu}<\mathrm{sMu} 0(1-\mathrm{cNcu} / \mathrm{Nk})$ のとき

$\mathrm{Mu}=$

$(1-(\mathrm{Nu}-\mathrm{cNcu}) / \mathrm{sNcr}) \cdot(1-(\mathrm{Nu}-\mathrm{cNcu}) / \mathrm{sNE}) \cdot(1-\mathrm{cNcu} / \mathrm{Nk}) \cdot \mathrm{sMu} / \mathrm{C}_{\mathrm{M}}$

式 (12) は Nuに関する3 次式, 式 (13) は 2 次式となる.

3. 5 鋼管指針の耐力と実倹耐力との対応

著者らは文献8)で鋼管指針によるコンクリート充填鋼管長柱の耐 力は, 荷重の偏心量が大きい場合には比較的良く耐力を評価するが, 偏心量が小さく，また材長が長いとかなり安全側に耐力を評価する ことを示した。

図-5に 2 章の実験概要で示した実験の角形断面でのカラムカーブ を示す. 図中○および○印でそれぞれコンクリート充填鋼管柱, 中 空鋼管柱の実験最大酎力を示している．また，実線で式 (2) で $\mathrm{Mu}=0$ として算定した鋼管指針の耐力, 破線で式 (5) で表せる鋼管柱の座 屈耐力を示している.

図 -5より鋼管指針の酎力は，座屈長さ・せい比が大きくなると， 点線で示す銅管柱の耐力に急速に漸近していることがわかる.しか し，実験値は急速には漸近していない，点線で示す中空鋼管柱の耐 力は実験酎力と良く対応していること，コンクリート充填鋼管柱の 座屈耐力は龬管柱の座屈荷重とコンクリート柱の座屈荷重を累加す ることにより良く評価出来る ${ }^{9}$ ことから，鋼管指針ではコンクリー 卜柱の耐力を座屈長さ・せい比が大きくなると過小評価しているこ とが推察される。

3.3 節で示したコンクリート柱の耐力は，1) 不可避の偏心を考虑 し，コンクリートの断面せいの $5 \%$ の偏心がある時の圧縮耐力を上 限としていること，2) 式 (10) で示されるようにモーメント拡大係 数の算定に対してコンクリート柱のオイラー座屈荷重の算定にコン 


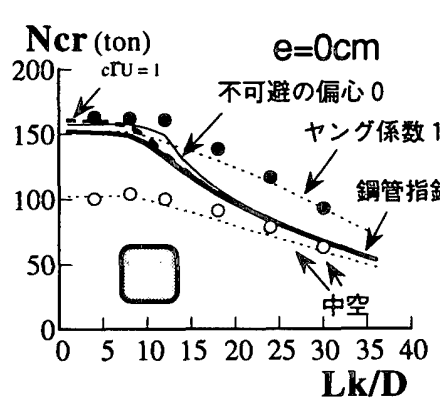

(a) $e=0 \mathrm{~cm}$

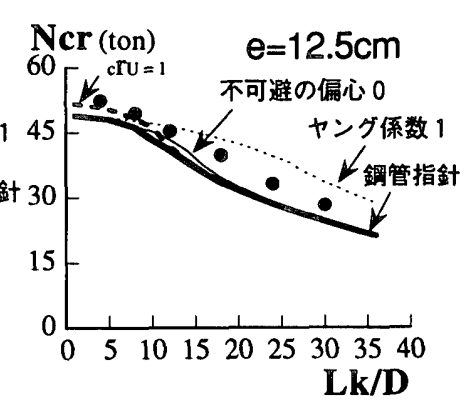

(b) $e=12.5 \mathrm{~cm}$

\section{図-6 ヤング係数等の値の耐力に及ほす影呟}

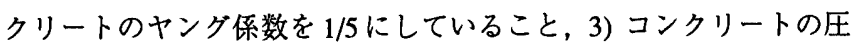
縮強度の低隇係数として cru $=0.85$ を取っていること，により過小評 価されている可能性がある.

鋼管指針の耐力式で上記 1) 一 3) までの操作を行わない場合の耐 力を図-6に示す. 図-6 (a) および (b) はそれぞれ瓦縮力の偏心量e が 0 (中心圧縮)，12.5cm の場合である. 图中太実線は鋼管指針の耐 力を示し，実線は不可避の偏心を考えない場合，破線はコンクリー トの強度低減係数を 1 とした場合, 点線はコンクリートのヤング係 数を $1 / 5$ 倍しない場合を示し，の印は実験最大耐力を示している.

図-6より，1）長柱域でもっとも耐力に影響を与えるのはコンク リートのヤンク係数であること，2) ヤング係数，コンクリート強度 の低減係数扩よび不可避の偏心量を単独に変化させるだけでは，短 柱域から長柱域まで適切には実験耐力は評価出来ないこと，が観察 され，コンクリート柱の適切な耐力評価が必要なことがわかる.

\section{4.コンクリート柱の耐力}

3.5 節で銅管指針が想定しているコンクリート柱の耐力は座屈長 さ・せい比が大きくなると耐力を過小評価していること、コンク リート柱の適切な耐力評価が必要なことを示した.

本章では, コンクリート柱の解析を行い，コンクリート柱の耐力 評価式を提示する．また，銅管指針が規定しているコンクリート柱 の耐力と比較する。

\section{1 解析モデルと解析方法}

図-7に示す材端に等偏心eの圧縮力を受ける正方形あるいは円形断 面コンクリート柱の解析を行った. 解析は材のたわみ形を式 (14)で 仮定し，材中央点の釣合いのみを考えた。

$$
\mathrm{u}=(\mathrm{e}+\delta) \sin (\pi \mathrm{x} / \mathrm{L})
$$

\section{2 応カーひずみ関係}

応力 $(\sigma)$ 一ひずみ $(\varepsilon)$ 関係は最大圧樎応力度までは式 (15) を用 い,その後は一定の応力度を維持すると仮定した．また，引張応力は 負担しないとした。

$$
\eta=1-(1-\xi)^{a}
$$

ここで， $\eta ， \xi ， \mathrm{a}$, は下式である.

$$
\begin{aligned}
& \eta=\sigma / \sigma \max \\
& \xi=\varepsilon / \varepsilon \max \\
& a=\mathrm{Ei} \cdot \varepsilon \max / \sigma \max
\end{aligned}
$$

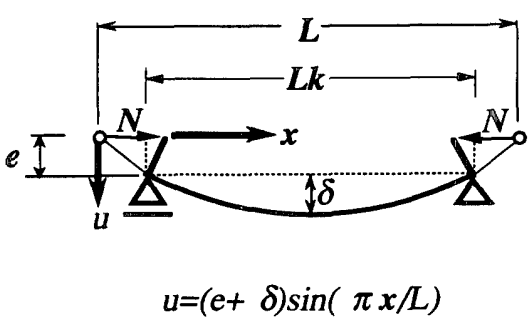

図-7 仮定したたわみ形 $\sigma \max \left[\mathrm{kg} / \mathrm{cm}^{2}\right]$ は圧縮強度， $\varepsilon \max$ は圧縮強度時のひずみで, $\varepsilon \max$ は下式を用いた ${ }^{13)}$.

$$
\varepsilon \max =0.52 \cdot(\sigma \max )^{0.25} \cdot 10^{-3}
$$

初期ヤング係数 Ei $\left[\mathrm{kg} / \mathrm{cm}^{2}\right]$ は式 (20) で求めた ${ }^{13)}$.

$$
\mathrm{Ei}=\left(0.106 \sigma \mathrm{max}^{0.5}+0.703\right) \cdot 10^{5}
$$

式 (18)によるaの值をコンクリート強度との関係で図-8に示して いる.

図 -9にコンクリートの圧縮強度と圧縮強度時のひずみ度, および 圧縮強度とヤング係数の関係を示す。

\section{3 解析変数}

解析変数として, コンクリートの設計基準強度 Fc, 座屈長さと断 面せい比に関係する変数 $\beta\left(=0.5 \cdot(\mathrm{Lk} / \mathrm{cD})^{2} \cdot \varepsilon \max : \mathrm{Lk}\right.$ は座屈長さ, cDは断面せい)を選んだ.

コンクリート強度 Fcは，240，360，480，600，720，840，960kg/ $\mathrm{cm}^{2}, \beta$ は $0.01,0.02,0.05,0.1,0.2,0.4,0.6,0.8,1.0,1.2,1.4$ を選び $\sigma \max$

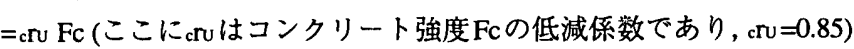
とした. 図-10に座屈長さ $(\mathrm{Lk}) \cdot$ 断面せい $(\mathrm{cD})$ 比と $\beta$ の関係を示す. 図-11に応力度 -ひずみ度関係を示す.

4. $4 \mathrm{cMu}-\mathrm{cNu}$ 関係の近似式

以上のコンクリート強度 Fc と $\beta$ の組合せに対して, 荷重の偏心量 $\mathrm{e}$ を種々変化させて, 圧縮力N一たわみ $\delta$ 関係を求めた。荷重一変形 関係より圧縮耐力を求め, 設計式の使用に必要な圧縮耐力 $\mathrm{cNu}$ 一端 モーメント $\mathrm{cMu}(=\mathrm{cNu} \cdot \mathrm{e})$ 関係を求めた.

設計式の使用で必要となる圧縮耐力 $\mathrm{cNu}$ 端モーメント $\mathrm{cMu}$ 関係 の解析解は得られないので, 解析結果より近似式を求めた。表-3に 設計用 $\mathrm{cMu}-\mathrm{cNu}$ 関係を算定するための式のまとめを示す．

表中の式 [1] がコンクリート柱の $\mathrm{cMu}-\mathrm{cNu}$ 関係である. 式 [1] 中 の cMmax は座屈長さ・せい比队に関係した最大モーメントであり断 面形にしたがい式 [2], [4] で与えられる (表-3中の図参照)。cMmax0 はコンクリート断面の最大モーメントであり，式 [3]，[5] で与えら れる。cNcrはコンクリート柱の座屈荷重であり, 式 [12] で与えられ る. 図 -12〜14に表-3中の諸量の算定図を示す.

図 -4に示した鋼管指針によるコンクリート柱の耐力に対応する 表-3により算定した耐力 (cru=0.85) を図-15に示す，また，図-16に は図-4および図-15より鋼管指針の規定しているコンクリート柱の酎 力と表 -3 の耐力を座屈長さ・せい比が 8 と 24 の場合について比較し て示す. 図-16より, 座屈長さ・せい比が 8 と小さい場合には鋼管指 針の耐力と表-3の精解值 (提案値) は比較的良く対応しているが, 24 


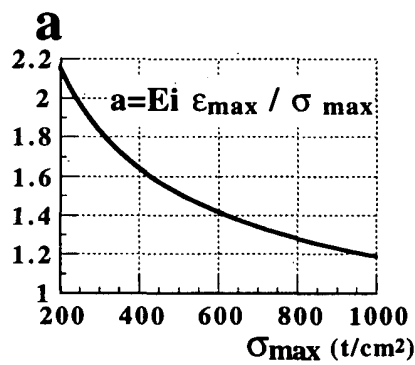

図 -8 指数 $\mathrm{a}$ の值

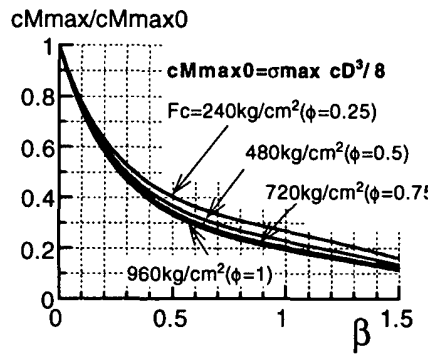

(a) 角形

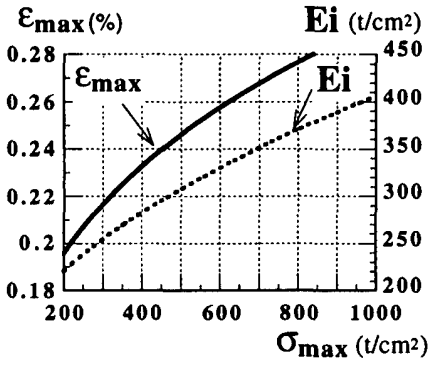

図 -9 強度時のひずみとヤング係数

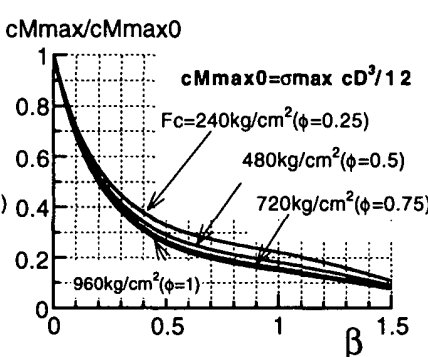

(b) 円形

图-12 cMmax 算定図（式 [2] と [4]）

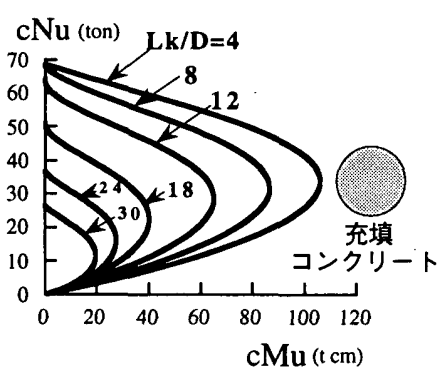

図-15 提案耐力

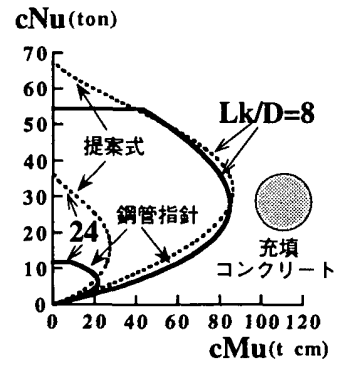

図-16 耐力の比較

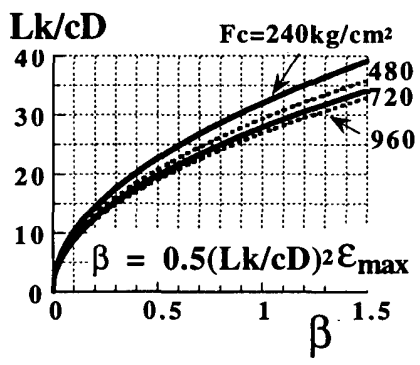

図-10 $\beta-\mathrm{Lk} / \mathrm{CD}$ 関係

$\mathrm{g}_{\mathrm{i}}(\phi)$

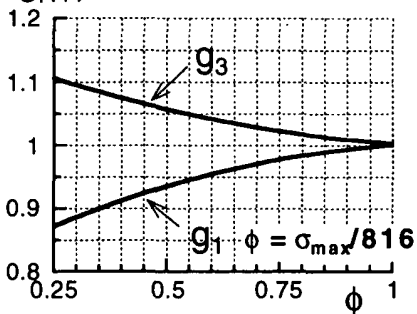

図-13 g1,g3算定図（式 [6] と [7]）

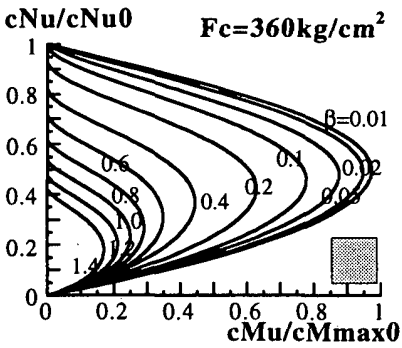

(a) 角形

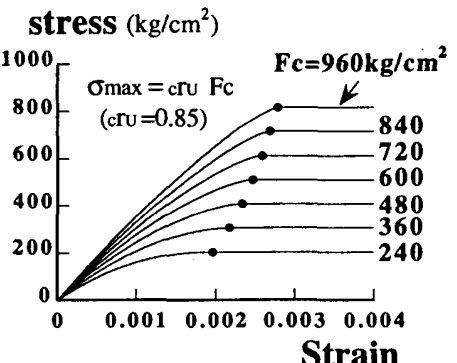

図-11 応カーひずみ関係

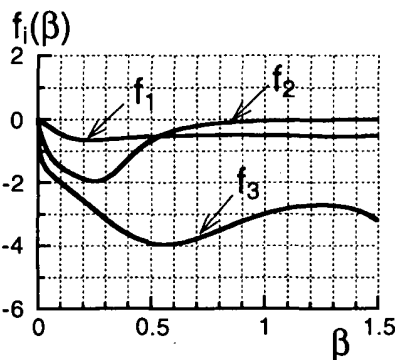

-14 $f 1, f 2, f 3$ 算定図 (式 [9] , [10]，[11])

$\mathrm{cNu} / \mathrm{cNuO} \quad \mathrm{Fc}=360 \mathrm{~kg} / \mathrm{cm}^{2}$

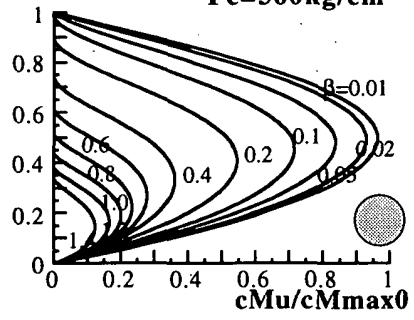

(b) 円形

図-17 cMu-cNu関係の例

\begin{tabular}{|c|c|c|}
\hline 記号 & 式 & \\
\hline$c M u-c N u \quad$ 相関関係 & $\begin{array}{l}c M u / c M \max = \\
\begin{aligned} 4(c N u / c N c r)\{I-(c N u / c N c r)\} & \\
{[1+f 1(\beta)((c N u / c N c r)-0.5)} & +f 2(\beta)((c N u / c N c r)-0.5)^{2} \\
& \left.+f 3(\beta)((c N u / c N c r)-0.5)^{3}\right]\end{aligned}\end{array}$ & $\cdots \quad[1]$ \\
\hline 角形断面のcMmax & $\begin{aligned} c M \max = & c M \max 0 \exp \left[-3.12 g I(\phi) \beta+2.21 \beta^{2}-0.73 I g 3(\phi) \beta^{3}\right] \\
& c M \max 0=\sigma \max c D^{3} / 8\end{aligned}$ & $\begin{array}{ll}\cdots & {[2]} \\
\cdots & {[3]}\end{array}$ \\
\hline 円形断面のcMmax & $\begin{aligned} c M \max = & c M \max 0 \quad \exp \left[-4.14 \mathrm{~g} 1(\phi) \beta+3.46 \beta^{2}-1.23 g 3(\phi) \beta^{3}\right] \\
& c M \max 0=\sigma \max c D^{3} / 12\end{aligned}$ & $\begin{array}{ll}\cdots & {[4]} \\
\cdots & {[5]}\end{array}$ \\
\hline 関数 $\mathrm{g} 1$ & $g I(\phi)=0.789+0.371 \phi-0.160 \phi^{2}$ & $\cdots \quad[6]$ \\
\hline$\underset{\phi}{\text { 関数 } g^{3}}$ & $\begin{array}{l}g(\phi)=1.17-0.285 \phi+0.118 \phi^{2} \\
\phi=\sigma \max /\left(0.85^{* 960)}=\sigma \max / 816\right.\end{array}$ & $\begin{array}{ll}\cdots & {[7]} \\
\cdots & {[8]}\end{array}$ \\
\hline 関数 $f$ ， & $f_{1}(\beta)=-\beta /\left(0.248-0.986 \beta+7.61 \beta^{2}-7.04 \beta^{3}+2.11 \beta^{4}\right)$ & $\cdots \quad[9]$ \\
\hline 関数 $f_{2}$ & $f_{2}(\beta)=-\beta /\left(0.0257+0.292 \beta+2.40 \beta^{2}-15.3 \beta^{3}+30.0 \beta^{4}\right)$ & $\cdots[10]$ \\
\hline 関数 $f_{3}$ & $f_{3}(\beta)=-\beta /\left(0.00360+0.591 \beta-1.46 \beta^{2}+1.90 \beta^{3}-0.702 \beta^{4}\right)$ & $\cdots[11]$ \\
\hline $\begin{array}{c}\text { 座屈荷重 }(c N c r=c N c u) \\
\text { 断面㿠 } c A\end{array}$ & $c N c r=c A \quad \sigma \max \left[1-(I-\varepsilon c r / \varepsilon \max )^{a}\right]$ & $\cdots[12]$ \\
\hline $\begin{array}{l}\varepsilon c r / \varepsilon \max \\
\text { 座屈時のひずみ }\end{array}$ & $\underset{\varepsilon c r}{(1-\varepsilon c r / \varepsilon \max )^{a}+a K(1-\varepsilon c r / \varepsilon \max )^{(a-l)}-1=0}$ & $\cdots[13]$ \\
\hline 圧縮強度時のひずみ & $\varepsilon \max =0.52 \sigma \max { }^{0.25} 10^{-3}$ & $\cdots[14]$ \\
\hline ヤング係数 & $E i=\left(0.106 \cdot \sigma \max { }^{0.5}+0.703\right) 10^{5}$ & $\cdots[15]$ \\
\hline 角形断面の $\boldsymbol{K}$ & $K=\pi^{2} /(24 \beta)$ & $\cdots[16]$ \\
\hline 円形断面の $\boldsymbol{K}$ & $K=\pi^{2} /(32 \beta)$ & $\cdots[17]$ \\
\hline$\beta$ & $\beta=0.5(L k / c D)^{2} \in \max$ & $\cdots[18]$ \\
\hline $\boldsymbol{a}$ & $a=E i \varepsilon \max / \sigma \max$ & $\cdots[19]$ \\
\hline
\end{tabular}

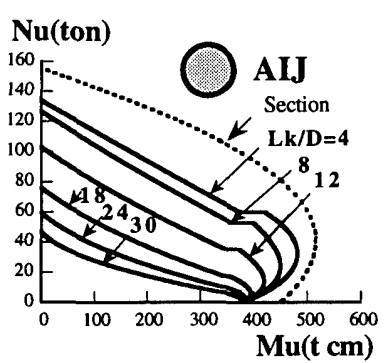

(a) 鋼管指針の酎力

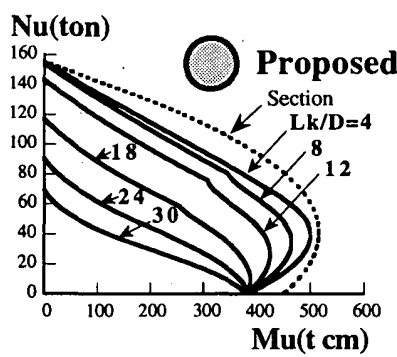

(b) 提案耐力

図-18 Mu-Nu関係 
と大きくなると鋼管指針の耐力はかなり安全側に耐力を評価している ことがわかる.

図 17 には，表 -3 に従って求めた $\mathrm{Fc}=360 \mathrm{~kg} / \mathrm{cm}^{2}$ の場合の $\mathrm{cMu}-\mathrm{cNu}$ 関 係を例示している. 付録には表-3による $\mathrm{cMu}-\mathrm{cNu}$ 関係の算定例を示 した.

\section{5. コンクリート充填鋼管長柱の終局耐力評価式の提案 \\ 5. 1 終局耐力評価式}

コンクリート充填鋼管長柱の終局耐力として, コンクリート柱の $\mathrm{cMu}-\mathrm{cNu}$ 関係を表-3による関係を用い，他は鋼管指針の式 (1) お よび (2) に従い算定する耐力を提案する。なお，式 (1) および (2) のcNcuはコンクリート柱の座屈荷重 $\mathrm{cNcr}$ 等しいとする。また, 式 (3) の中のコンクリートのヤング係数 $\mathrm{cE}$ は, 表 -3 の式 [15] の $\mathrm{Ei}$ と する ( $\mathrm{cE}=\mathrm{Ei})$.

\section{2 実験耐力との比較}

鋼管指針では，座屈長さ・せい比が 12 を境に短柱と長柱に分け， 両者で設計式は異なっているが，ここでは，座屈長さ・せい比の值 にかかわらず，すべてを長柱として扱い，実験酎力と比較する．コ ンクリート柱の预力として表-3による耐力を用いてコンクリート充 填鋼管柱の耐力を算定した提案耐力に加えて, 鋼管指針の耐力も算 定している. 表-3によるコンクリート柱の耐力の算定には, コンク リートの圧縮強度の低隇係数 $\mathrm{cr}$ の值としては 1 と 0.85 を設定した。

図-18 および図-19に耐力に関する $\mathrm{Mu}(=\mathrm{Nu}$ e) - $\mathrm{Nu}$ 相関関係を示 す. 図-18 は 2 章に示した円形断面の $\mathrm{Mu}-\mathrm{Nu}$ 関係を例示している. 図-18 (a) は鋼管指針の耐力であり，(b) は提案耐力である．図-18

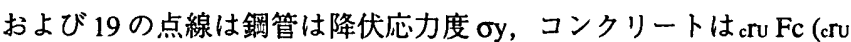
=1)で全塑性応力分布を仮定した断面耐力である.

図-19にはの印で充填鋼管の実験耐力を，○印で中空鋼管の実験 耐力を示す．また，太実線で提案耐力 Nmod1（図中Proposed）, 点線 で鋼管指針の酎力（図中 AIJ），細実線で式 (4)で与えられる鋼管柱 の耐力を示す. 太実線の提案酎力はコンクリート柱の耐力を強度低 減係数 $\mathrm{cru=1}$ として算定した耐力である.

表 $-4,5$ に, 実験耐力および酎力算定値の比較を示す. 表中のNexp は実験耐力, Nsrc は鋼管指針の耐力, NmodおよびNmod1 はそれぞ れ，コンクリート柱の耐力算定に $\mathrm{cru}=0.85 ， 1.0$ とした酎力である.

図-20および21には実験耐力と計算耐力の関係を示している. 表6には，(実験耐力／計算耐力）の値の統計量を示している.

図-19および表 $-4,5$ より，鋼管指針の耐力と実験酎力の値の違い は，材長が長くなるほど，また偏心距離が小さくなるほど大きくな る傾向にあることがわかる.

提案耐力は座屈長さ・せい比の広い範囲で実験の $\mathrm{Mu}-\mathrm{Nu}$ 関係を よく予測している. 円形断面で座屈長さ・せい比が 4 の場合は, 提案 耐力の Mu-Nu関係では，実験值をかなり安全側に評価している。こ の原因は，式 (1)，(2) に関して，1) その耐力が最大で断面の単純累 加強度しか与えないこと，2) 式 (3) で与えられる鋼管柱の耐力式は, 断面の耐力 $\left(\mathrm{sN}_{\mathrm{E}} \rightarrow \infty\right)$ としても $\mathrm{sNu}$ と $\mathrm{sMu}$ に関して直線の相関関係 しか与えず, 断面の全塑性に関する相関曲線を与えないこと, さらに 3）鋼管とコンクリートの相互作用 (コンファインド効果), および4) 鋼管のひずみ効果による耐力上昇，が原因であると考えられる.

表 $-4,5$ および 6 より，銅管指針による耐力は，充填龬管ではすべ
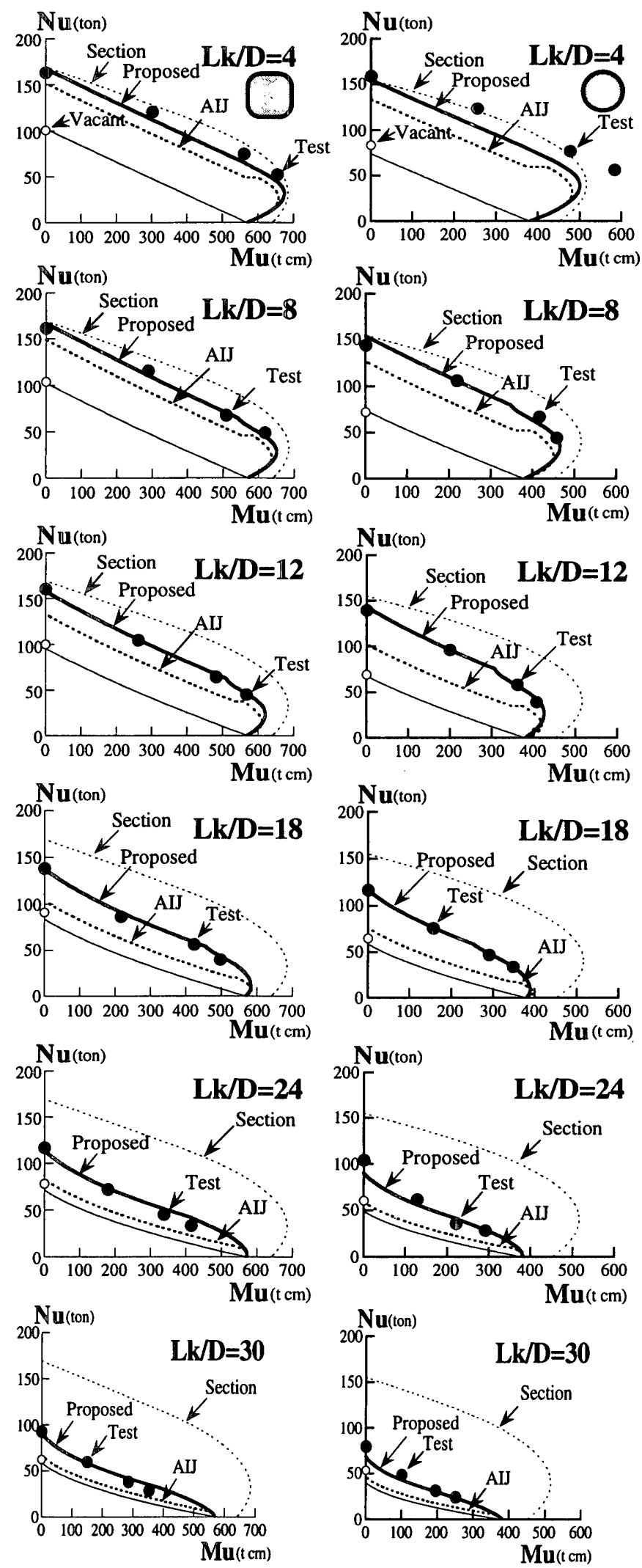

(a) 角形

(b) 円形

図-19 耐力の比較

て安全側の耐力評価をしているが，角形断面で 6.9 40\%, 円形断面 で6.7〜 75.5\%と実験酎力との差は大きく，また，ばらつきも大きい，

提案耐力は, 表-6に示すように（実験耐力／計算耐力）の値の平 均値および変動係数は, 角形断面で $1.04,4.9 \%$ ( $\mathrm{cr}=0.85), 0.99,4.0 \%$ 

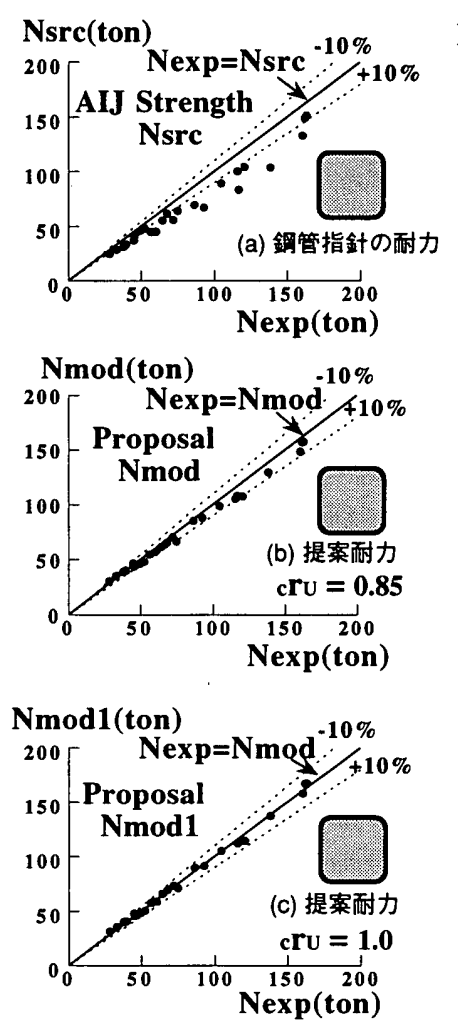

図-20 耐力の比較（角形）
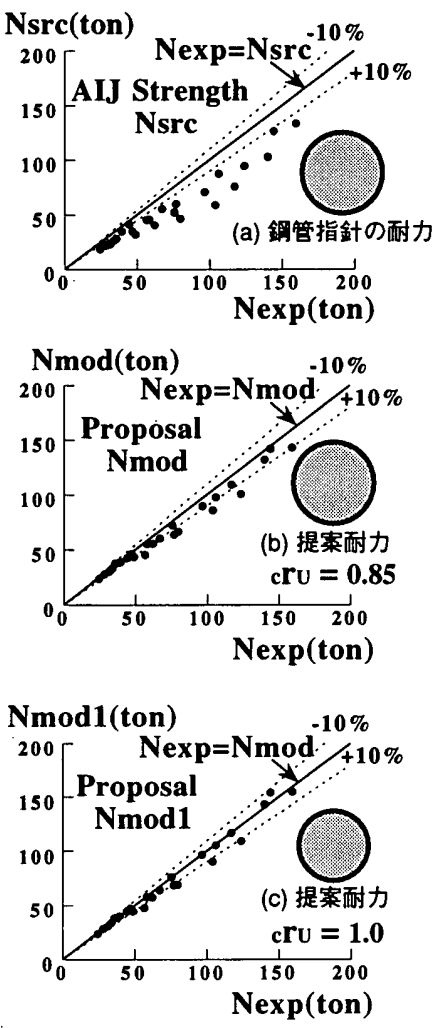

図-21耐力の比較（円形）

(cru=1.0), 円形断面で 1.08, 6.8\% ( $\mathrm{cru}=0.85), 1.03,6.2 \%$ ( $\mathrm{cru}=1.0)$ と 精度良く実験耐力を評価しており, また, 変動係数も小さな值となっ ている.

実験データがさらに集積されると，限界状態設計法の手順に従っ て本論文で提示した耐力評価式に対応する耐力係数を提示出来よう. 耐力評価式としては, コンクリート強度の低隇係数 $\mathrm{cr}$ の值に関して cru=1 とした方が 0.85 とする場合より, 変動係数は小さくまた, 平均 值も 1 に近く平均的には良い耐力評価をしている. しかし，検討し た試験体 47 体の内 20 体が危険側の評価をしていることから, 設計 式としては， 47 体中 5 体が危険側となった $\mathrm{ru}=0.85$ を用いれば概ね 安全側にかつ精度良くコンクリート充填鋼管柱の耐力を評価出来る. なお，高強度コンクリートを用いた場合の耐力評価式の精度は今後 検討する必要がある。

\section{3 モーメント勾配のある場合の耐力評価法}

5.2節で, 軸力と等曲げを受ける長柱の耐力は精度良く評価出来る ことを示した.ここでは, 曲げモーメントに勾配のある長柱の酎力 評価法について考察する.コンクリート充填鋼管柱を鉄骨柱と考え， 文献 11)に準ずれば以下のようになる.

i) 軸力と等曲げを受けるCFT長柱の曲げ耐力を 5.1 節で示した方法 で算出する。

ii) 曲げモーメント分布により定まる倸数 $\mathrm{C}_{M}$ を下式で算定する ${ }^{11)}$.

但し, 柱頭の水平変位が拘束されていない柱においては, $\mathrm{C}_{\mathrm{M}}=1$ とする ${ }^{11)}$.

$\mathrm{C}_{\mathrm{M}}=1-0.5\left(1-\mathrm{M}_{2} / \mathrm{M}_{1}\right)(\mathrm{Nu} / \mathrm{Nk})^{0.5} \geqq 0.25$

ここで, $\mathrm{M}_{1}, \mathrm{M}_{2}$ : 柱の両端に作用する曲げモーメントのうち，そ れぞれ絶対值が大きいほうおよび小さいほうの值で, $\mathrm{M}_{2} / \mathrm{M}_{1}$ は柱

表 -4 耐力の比較（角形）

\begin{tabular}{|c|c|c|c|c|c|c|c|c|c|}
\hline Specimen & $L k / D$ & & Nexp & & esign Stre & ength & Err & or $(=\mathrm{Nex}$ & $\mathrm{p} / \mathrm{N}^{*}-1$ \\
\hline & & $(\mathrm{cm})$ & (ton) & Nsre & $\begin{array}{c}\text { Nmod } \\
r_{v}=0.85\end{array}$ & $\begin{array}{l}\text { Nmodl } \\
r_{v}=1\end{array}$ & Nsrc & $\begin{array}{r}\text { Nmod } \\
r_{v}=0 .\end{array}$ & $\begin{array}{l}\text { NmodI } \\
r_{v} r_{v}=1\end{array}$ \\
\hline C4-0 & 4 & 0.00 & 162.9 & 151.4 & 157.5 & 167.3 & $7.6 \%$ & $3.4 \%$ & $-2.6 \%$ \\
\hline$C_{A}$ & 4 & & .7 & 103.8 & & 114.6 & $16.2 \%$ & & $3 \%$ \\
\hline & 4 & 7.50 & & 64.1 & & 70.7 & $5.8 \%$ & $\%$ & $5.8 \%$ \\
\hline C & 4 & 12.50 & & 48.3 & .9 & 50.5 & & $.4 \%$ & $3.8 \%$ \\
\hline & 4 & & & 102.4 & & 102.4 & $-2.0 \%$ & 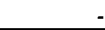 & \\
\hline C & 8 & 0.00 & 1.7 & 148.7 & 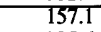 & 166.9 & $8.8 \%$ & $2.9 \%$ & $-3.1 \%$ \\
\hline & 8 & 2.50 & & 100.1 & & 12.0 & $15.4 \%$ & & $3.1 \%$ \\
\hline c & 0 & 7.50 & & 61. & & 69.0 & 10. & & $-1.7 \%$ \\
\hline & 8 & 12.50 & & 46.2 & & 48.4 & $6.9 \%$ & $\%$ & $2.1 \%$ \\
\hline & 8 & 0.00 & 103.8 & 102.4 & & 102.4 & $1.3 \%$ & & \\
\hline C12 & & 0.00 & 160.4 & 132.7 & & 57.8 & $20.9 \%$ & $\%$ & $1.7 \%$ \\
\hline & 1 & 2.50 & & 89. & & 104.9 & 17. & & $-0.4 \%$ \\
\hline & & & & 55 & & 5.6 & 15 & & $-2.0 \%$ \\
\hline & 12 & 12.50 & & 40.9 & & 45.6 & $10.9 \%$ & $7 \%$ & $-0.4 \%$ \\
\hline & 12 & & 0.21 & 95.3 & & 95.3 & $5.1 \%$ & 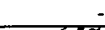 & \\
\hline C18- & 18 & 0.00 & 138.3 & 103.7 & 129.8 & 137.3 & $33.4 \%$ & $6.5 \%$ & $0.7 \%$ \\
\hline & & & & 69 & & 89.6 & 24. & & $-3.7 \%$ \\
\hline & 1 & & & 44.8 & & 57.5 & $25.9 \%$ & 2 & $-2.0 \%$ \\
\hline & & 12. & & & & 40.8 & $18.5 \%$ & $0.3 \%$ & $-2.5 \%$ \\
\hline & 1 & 0.00 & & 83 & & 83.4 & & & \\
\hline C2 & & & 116.6 & & & 113.4 & $40.0 \%$ & 7. & $2.8 \%$ \\
\hline & 2 & & & & & 73.0 & 29. & & $-1.5 \%$ \\
\hline & & & & & & 48.2 & 21 . & & $-6.6 \%$ \\
\hline & & 12 & & & & 35.8 & $16.7 \%$ & $-5.7 \%$ & $-7.3 \%$ \\
\hline & & & & & & 71.5 & & & \\
\hline C3 & 3 & 0. & 92 & 67 & 9 & 91.2 & $37.9 \%$ & $\%$ & $1.7 \%$ \\
\hline & & & & & & & & & $2.2 \%$ \\
\hline & 30 & 7. & 38 & 31 & & 40.1 & $21.6 \%$ & & $-5.3 \%$ \\
\hline & 3 & 12. & 28 & 24 & & 31.2 & $15.1 \%$ & $-7.7 \%$ & $-9.6 \%$ \\
\hline $30=0$ & 30 & & 02.8 & 59.6 & 59.6 & 59.6 & $5.4 \%$ & 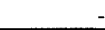 & \\
\hline
\end{tabular}

表 -5 耐力の比較（円形）

\begin{tabular}{|c|c|c|c|c|c|c|c|c|c|}
\hline Specimen & $L k / D$ & & Nexp & & esign Stre & ngth & Err & cor $(=\mathrm{Nexp}$ & $\left(\mathrm{N}^{*}-1\right)$ \\
\hline & & (cm) & (ton) & Nsrc & $\begin{array}{c}\text { Nmod } \\
r_{v}=0.85\end{array}$ & $\begin{array}{l}\text { NmodI } \\
r_{v}=1\end{array}$ & Nsrc & $\begin{array}{c}\text { Nmod } \\
r_{v}=0.85\end{array}$ & $\begin{array}{l}\text { Nmodl } \\
r_{v}=1\end{array}$ \\
\hline$\overline{C 4-0}$ & $\overline{4}$ & 0.00 & 159.3 & 133.7 & 142.8 & 154.9 & $19.1 \%$ & $11.6 \%$ & $2.8 \%$ \\
\hline C4-1 & 4 & 2.07 & 123.7 & 94.6 & 100.8 & 109.3 & $30.8 \%$ & $22.7 \%$ & $13.1 \%$ \\
\hline C4-3 & 4 & 6.20 & 76.9 & 60.0 & 63.7 & 68.7 & $28.1 \%$ & $20.7 \%$ & $11.9 \%$ \\
\hline C4-5 & 4 & 10.32 & 56.5 & 45.3 & 45.3 & 47.8 & $*$ & $*$ & * \\
\hline S4-0 & 4 & 0.00 & 83.9 & 74.2 & 74.2 & 74.2 & $13.1 \%$ & - & \\
\hline C8-0 & 8 & 0.00 & 144.0 & 126.5 & T41.9 & 154.0 & $13.9 \%$ & $1.5 \%$ & $-6.5 \%$ \\
\hline C8-1 & 8 & 2.07 & 106.1 & 87.5 & 97.6 & 105.7 & $21.3 \%$ & $8.7 \%$ & $0.4 \%$ \\
\hline C8-3 & 8 & 6.20 & 67.1 & 55.4 & 60.2 & 64.1 & $21.1 \%$ & $11.5 \%$ & $4.7 \%$ \\
\hline C8-5 & 8 & 10.32 & 44.3 & 41.5 & 42.4 & 44.3 & $6.7 \%$ & $4.5 \%$ & $0.0 \%$ \\
\hline S8-0 & 8 & 0.00 & 72.2 & 74.0 & 74.0 & 74.0 & $-2.4 \%$ & - & \\
\hline C12-0 & 12 & 0.00 & 139.9 & 102.7 & 132.0 & 143.3 & $36.2 \%$ & $6.0 \%$ & $-2.4 \%$ \\
\hline C12-1 & 12 & 2.07 & 96.6 & 70.9 & 89.5 & 96.5 & $36.3 \%$ & $7.9 \%$ & $0.1 \%$ \\
\hline $\mathrm{Cl2}-3$ & 12 & 6.20 & 58.2 & 45.7 & 55.0 & 57.9 & $27.3 \%$ & $5.8 \%$ & $0.5 \%$ \\
\hline C12-5 & 12 & 10.32 & 39.4 & 34.9 & 38.7 & 40.0 & $12.8 \%$ & $1.8 \%$ & $-1.5 \%$ \\
\hline S12-0 & 12 & 0.00 & 69.6 & 67.8 & 67.8 & 67.8 & $2.7 \%$ & . & \\
\hline C18-0 & 18 & 0.00 & 177.0 & 75.8 & 109.5 & 117.0 & $54.4 \%$ & $6.9 \%$ & $0.0 \%$ \\
\hline C18-1 & 18 & 2.07 & 75.6 & 52.2 & 72.1 & 76.1 & $44.9 \%$ & $4.9 \%$ & $-0.7 \%$ \\
\hline C18-3 & 18 & 6.20 & 46.9 & 34.7 & 46.0 & 47.4 & $35.3 \%$ & $2.0 \%$ & $-1.1 \%$ \\
\hline C18-5 & 18 & 10.32 & 33.7 & 26.4 & 33.0 & 33.7 & $27.5 \%$ & $2.1 \%$ & $0.0 \%$ \\
\hline S18-0 & 18 & 0.00 & 64.9 & 58.5 & 58.5 & 58.5 & $10.9 \%$ & 2.00 & \\
\hline C24-0 & 24 & 0.00 & 103.9 & 59.2 & 85.9 & 90.2 & $\begin{array}{l}75.5 \% \\
\end{array}$ & $20.9 \%$ & $15.1 \%$ \\
\hline C24-1 & 24 & 2.07 & 62.1 & 40.7 & 55.7 & 57.7 & $52.6 \%$ & $11.5 \%$ & $7.6 \%$ \\
\hline C24-3 & 24 & 6.20 & 35.7 & 28.0 & 37.5 & 38.2 & $27.7 \%$ & $-4.8 \%$ & $-6.5 \%$ \\
\hline C24-5 & 24 & 10.32 & 28.2 & 21.8 & 27.9 & 28.4 & $29.2 \%$ & $1.1 \%$ & $-0.7 \%$ \\
\hline S24-0 & 24 & 0.00 & 60.6 & 49.2 & 49.2 & 49.2 & $23.1 \%$ & 10 & \\
\hline C30-0 & 30 & 0.00 & 79.7 & 46.4 & 66.4 & 69.0 & $71.6 \%$ & $20.1 \%$ & $15.5 \%$ \\
\hline C30-1 & 30 & 2.07 & 48.8 & 32.2 & 43.3 & 44.4 & $51.6 \%$ & $12.7 \%$ & $9.9 \%$ \\
\hline C30-3 & 30 & 6.20 & 31.5 & 23.0 & 30.1 & 30.8 & $37.2 \%$ & $4.7 \%$ & $2.3 \%$ \\
\hline C30-5 & 30 & 10.32 & 24.3 & 18.4 & 23.5 & 23.8 & $32.3 \%$ & $3.4 \%$ & $2.1 \%$ \\
\hline S30-0 & 30 & 0.00 & 53.9 & 40.0 & 40.0 & 40.0 & $34.8 \%$ & - & \\
\hline
\end{tabular}

* : ピン支持不完全 $(\mathrm{C} 4-5)$

表 -6 充填鋼管柱の Nexp / N* の統計量

\begin{tabular}{|c|c|c|c|c|c|c|}
\hline \multirow[b]{2}{*}{ 統計量 } & \multicolumn{3}{|c|}{ 角形断面 } & \multicolumn{3}{|c|}{ 円形断面 } \\
\hline & $\frac{\text { Nexp }}{\text { Nsrc }}$ & $\frac{\text { Nexp }}{\text { Nmod }}$ & $\frac{\text { Nexp }}{\operatorname{Nmod1} 1}$ & $\frac{\text { Nexp }}{\text { Nsrc }}$ & $\frac{\text { Nexp }}{\text { Nmod }}$ & $\frac{N \operatorname{Nexp}}{\operatorname{Nmod} 1}$ \\
\hline 平均值 & 1.20 & 1.04 & 0.99 & 1.34 & 1.08 & 1.03 \\
\hline 最小值 & 1.07 & 0.92 & 0.90 & 1.07 & 0.95 & 0.93 \\
\hline 最大值 & 1.40 & 1.12 & 1.06 & 1.76 & 1.23 & 1.16 \\
\hline 変動係数 & $7.9 \%$ & $4.9 \%$ & $4.0 \%$ & $13.0 \%$ & $6.8 \%$ & $6.2 \%$ \\
\hline
\end{tabular}

$\mathrm{N}^{*}$ : Nsrc, Nmod, Nmod1 
が単曲率の場合に正，複曲率の場合に負とする．Nuは柱に作用 する軸圧縮力, Nk はオイラー座屈強度で, 式 (3) で算定する.

iii） i）で算定した曲げ耐力をii) の $\mathrm{C}_{M}$ で除することにより，モーメ ント勾配のある場合の耐力とする。

以上をまとめると，モーメント勾配のある場合の酎力評価式は式 (22)，(23) となる。 なお, 式 (22), (23) 右辺の曲げモーメント, 軸 力に関する量は等曲げに関する量である.

$\mathrm{Nu} \leqq \mathrm{cNcu}$ または $\mathrm{Mu} \geqq \mathrm{sMu0}(1-\mathrm{cNcu} / \mathrm{Nk})$ のとき

$\mathrm{Nu}=\mathrm{cNu}$

$\mathrm{Mu}=\{\mathrm{cMu}+\mathrm{sMu} 0(1-\mathrm{cNu} / \mathrm{Nk})\} / \mathrm{C}_{\mathrm{M}}$

$\mathrm{Nu}>\mathrm{cNcu}$ または $\mathrm{Mu}<\mathrm{sMu0}(1-\mathrm{cNcu} / \mathrm{Nk})$ のとき

$\mathrm{Nu}=\mathrm{cNcu}+\mathrm{sNu}$

$\mathrm{Mu}=\{\mathrm{sMu}(1-\mathrm{cNcu} / \mathrm{Nk})\} / \mathrm{C}_{\mathrm{M}}$

\section{6. 結論}

コンクリート充填鋼管柱の中心および偏心圧縮実験結果に基づき， 鋼管構造設計施工指針の耐力式を検討し、コンクリート充填鋼管長 柱の終局耐力評価式を提示した。

提示した㓦力評価式は現行の設計式 (1)，(2) において，コンク リート柱の耐力 $\mathrm{cMu}-\mathrm{cNu}$ 関係を表-3に基づき算定する事のほかは 現行の設計式と同様である。

本論文で得られた知見は以下のようにまとめられる。

1）鋼管構造設計施工指針による㓦力は, 荷重の偏心量が大きい場 合には，安全側で比較的よく耐力を予測する。しかしながら，実 験値との誤差は, 偏心量が小さく，また，材長が長い程大きく なる。

2）結論 1 ）の理由は，鋼管指針の想定しているコンクリート柱の 耐力は座屈長さ・せい比が大きくなると耐力を過小評価してい るためである。

3) コンクリート柱の酎力を表-3に示すように提示する.

4 ) コンクリート柱の耐力として結諭3)に示した酎力を用い, その 他は現行の長柱の設計式 (1) および (2) に従う算定法をコンク リート充填鋼管長柱の耐力評価法として提案する。

5 ）提案した耐力は, cru=1 としてコンクリート柱の酎力を算定すれ ば，平均的に実験耐力を一番精度良く評価できる．安全側に耐 カを評価するためには、ru=0.85としてコンクリート柱の耐力を算 定すれば良い。

6）モーメント勾配のある場合の酎力評洒法を式 (22)，(23)のよj に提案する.

謝辞

本研究は, 鋼材俱楽部（鋼管コンクリート構造研究会・長柱設計法WG, 委員長高田啓一) の援助を得ました。 また，長柱設計法WG 前委員長，故 松村弘道博士には, 貴重な意見を頂きました. 実験に際し, 九州大学技官, 有働文久，川口晃，久島昭久，津賀山健次の諸氏，実験および資料整理に 際して, 上田大成 (大成建設, 当時九州大学大学院学生), H.Z.E. Din博 士 (アレキサンドリア大学, 当時九州大学大学院学生), 尾崎功 (大成建 設, 当時九州大学大学院生), 美野英司 (当時九州大学学生) の諸氏のご協 力を得ました.ここに，深く感謝致します。

\section{参考文献}

1) 松井千秋: コンクリート充填鋼管構造の構造性能と設計, 鎆構造論 文集, 第 1 巻第 2 号, pp.11-24, 1994. 6.

2) 柴田道生：SRC 梁一柱の耐力評価式, 構造工学論文集, Vol. 40B, pp.351-358, 1994. 3 .

3) 柴田道生：SRC梁一柱の耐力, 構造工学論文集, Vol. 40B, pp.359-366, 1994. 3.

4) 日本建築学会 : 鉄骨鉄筋コンクリート構造計算规準・同解説, 1987.6.

5) 日本建築学会：鋼管構造設計施工指針・同解説, 1990.1 .

6) 若林賽, 吉田望: 細長い合成柱の設計式, 日本建築学会論文報告集, 第 278 号, pp.27-36, 1979. 4 .

7) 若林実：龬管コンクリート構造の最近における発展, GBRC, Vol. 65, pp.8-17, 1992.1.

8) 松井千秋, 津田惠吾, 尾崎 功, 石橋靖夫: コンクリート充填鋼管長 柱の耐力, 日本建築学会構造系論文報告集, 第 494 号, 1997.4 .

9) 津田恵吾, 松井千秋: コンクリート充填銅管柱の累加座屈荷重, 銅 構造論文集, 第 3 巻第 9 号, pp. 11-18, 1996. 3.

10) 律田恵吾, 松井千秋, 石橋靖夫: コンクリート立填鋼管柱の座屈耐 力, 構造工学論文集 Vol. 42B, pp. 485-494, 1996. 3.

11) 日本建築学会：鎆構造塑性設計指針, 1975.11.

12) 日本建築学会：鎆構造座屈設計指針, 1996.1.

13) 崎野健治, 孫 玉平: 直線型横補強材により拘束されたコンクリー 卜の応力ーひずみ関係, 日本建築学会構造系論文報告集, 第 461 号, pp. 95-104, 1994. 7.

付録

$\mathrm{cMu}-\mathrm{cNu}$ 関係の算定例として，付図 -1 に示寸角形鋼管柱に充填され たコンクリート柱の $\mathrm{cMu}-\mathrm{cNu}$ 関係を求める.

角形鋼管の幅 $\mathrm{D}$ は $50 \mathrm{~cm}$, 板厚 $\mathrm{t}=2.5 \mathrm{~cm}$ とし, 座屈長さと断面せいの 比 Lk/D は 24 とする．コンクリートの設計基準強度 $\mathrm{Fc}$ は $300 \mathrm{~kg} / \mathrm{cm}^{2}$ とす る. また, コンクリート強度 Fcに対する低減係数 cruは 0.85 とする。 な お，以下の式番号は表-3の中の式番号に対応している.

コンクリートの圧縮強度 $\sigma \mathrm{max}=\mathrm{cru} \cdot \mathrm{F}=0.85 \cdot 300=255 \mathrm{~kg} / \mathrm{cm}^{2}$. 式 [14] より，圧縮強度時のひずみ $\mathrm{Emax}=0.52 \cdot 255^{0.25} \cdot 10^{-3}=0.00208$ (図 -9 参照): 式 [15] , [19] より, ヤング係数 $\mathrm{Ei}=\left(0.106 \cdot(255){ }^{0.25}+0.703\right) \cdot 10^{5}=240000 \mathrm{~kg} /$ $\mathrm{cm}^{2}$, 指数 $\mathrm{a}=240000 \cdot 0.00208 / 255=1.95$ (図 $-9,8$ 参照).

座屈長さ $\mathrm{Lk}=24 \cdot 50=1200 \mathrm{~cm}$, コンクリートの断面せい $\mathrm{cD}=\mathrm{D}-2 \mathrm{t}=45 \mathrm{~cm}$, $\mathrm{Lk} / \mathrm{cD}=1200 / 45=26.7$. 式 $[18]$ より $\beta=0.5 \cdot 26.7^{2} \cdot 0.00208=0.739$ （図 -10 参照). 式 [9] - [11] より, f1 $(\beta=0.739)=-0.505, \mathrm{f} 2(\beta=0.739)=-0.171$, f3 $(\beta=0.739)=-3.69$ (図-14 参照).

式 [3] より, $\mathrm{cMmax} 0=255 \cdot 45^{3} / 8=2900000 \mathrm{~kg} \mathrm{~cm}=29.0 \mathrm{tm}$

式 [8] より, $\phi=255 / 816=0.313$. 式 [6], [7] より $\mathrm{g} 1(\phi)=0.889, \mathrm{~g} 3$ $(\phi)=1.09$ (図-13参照). 式 [2]より, cMmax/cMmax $0=\exp (-3.12 \cdot 0.889 \cdot$ $\left.0.739+2.21 \cdot 0.739^{2}-0.731 \cdot 1.09 \cdot 0.739^{3}\right)=0.312$ (図 -12 参照).

したがって, cMmax $=29.0 \cdot 0.312=9.05$ tonm.

式 [13] より，座屈時のひすみ $\varepsilon c r=0.0008654 ， \sigma \mathrm{cr} / \sigma \mathrm{max}=0.651, \sigma \mathrm{cr}=0.651$. $255=166 \mathrm{~kg} / \mathrm{cm}^{2}$, 座屈荷重 $\mathrm{cNcr}=166 \cdot 2025=336000 \mathrm{~kg}=336 \mathrm{ton}$.

以上より $\beta=0.739, \mathrm{f} 1 \quad(\beta=0.739)=-0.505, \mathrm{f} 2(\beta=0.739)=-0.171, \mathrm{f} 3$ $(\beta=0.739)=-3.69, \mathrm{cMmax}=9.05 \mathrm{tm}, \mathrm{cNcr}=336 \mathrm{ton}$ と求まり, 式 [1] より cMu$\mathrm{cNu}$ 関係は下式となる. 付図 -2 に下式の $\mathrm{cMu}-\mathrm{cNu}$ 関係を示す.

$\mathrm{cMu} / 9.05=4 \cdot(\mathrm{cNu} / 336) \cdot\{1-(\mathrm{cNu} / 336)\} \cdot\{1+(-0.505) \cdot((\mathrm{cNu} / 336)-0.5)$ $\left.+(-0.171) \cdot((\mathrm{cNu} / 336)-0.5){ }^{2}+(-3.69) \cdot((\mathrm{cNu} / 336)-0.5)^{3}\right)$

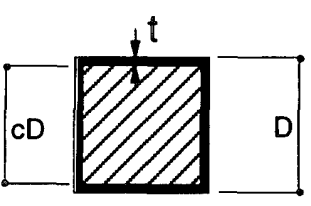

付图-1 計算例の断面

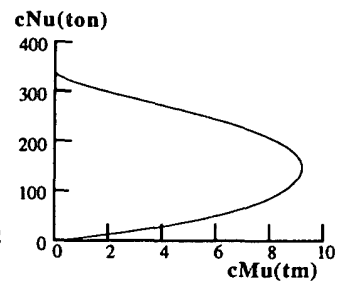

付図 -2 cMu-cNu 相関関係

（1996年12月10日原稿受理，1997年 2 月13日採用決定） 